\title{
Determinants of Capital Formation of Smallholder Farmers in Kyrgyzstan
}

\author{
Dr. Dastan Aseinov (Kyrgyz-Turkish Manas University, Kyrgyzstan) \\ Asst. Prof. Dr. Burulcha Sulaimanova (Kyrgyz-Turkish Manas University, Kyrgyzstan) \\ Asst. Prof. Dr. Kamalbek Karymshakov (Kyrgyz-Turkish Manas University, Kyrgyzstan)
}

\begin{abstract}
Capital formation is crucial to increase output volume and quality in agricultural production activity of households. This study examines factors affecting capital formation of smallholder farmers in Kyrgyzstan ranging from household characteristics to location of farmers. Along with other traditional potential constraints that may have impact on capital formation, we examine the role of social network activities. These expenditures on customs and traditions may have both negative and positive effects on the capital formation in agriculture. Our empirical analysis is based on the cross-sectional household survey data for 2013. According to our findings, the amount of physical assets of households in Kyrgyzstan mainly depends on the share of expenses on customs and traditions, the total income, gender differences and the ethnicity of the head of household.
\end{abstract}

\section{Introduction}

Capital formation of small land holders is crucial in addressing long-term sustainable economic development challenges, as it affects productivity of farmers and poverty of households (Herr, 1964). Economic literature defines different types of household capital: human capital, social capital, natural capital, financial capital, physical capital and public capital (Mwanza \& Speelman, 2011). Among them accumulation of physical capital is important for increasing productivity of small landholders, especially in the case of less industrialized low-income transition economies such as Kyrgyzstan where most of income generating activities of rural households are linked to agricultural sector.

Most part of the corresponding literature indicates that physical capital formation of households are affected by savings, income level, size of owned land, access to finance, agricultural infrastructure, age of household head, environmental shocks and macroeconomic indicators.

However, along with these determinants, accumulation of physical capital is interrelated with other types of household capital - social and human capital. Therefore, it can be stated that physical capital should not be considered separately from other types of capital. Moreover, social capital considered as complementary to human and physical capital, and not an isolated factor in agricultural production. Thus, Grootaert (1999) examined relationship between social capital, household welfare and poverty in Indonesia and showed that households with high social capital are better able to accumulate physical assets and savings and to obtain credit. Similar findings obtained by Winters et al. (2009) confirm positive relationship between key assets, income the income-generating activities and welfare of rural households in developing countries. Another study by O'Brien et al. (2000) analysing social, human and physical capital of Russian peasant households revealed that some households could translate advantages in human and social capital into physical capital due to adaptation to market economy. Human capital is considered as important factor and even availability of other resources for capital accumulation may not provide with sustainability. In this regard, study by Walle (2003) on Vietnamese case concludes that even if access to finance will be provided to poor households, it should not be expected, that they escape from poverty, since the return on physical capital, to which borrowed funds are channelled, is strongly correlated with human capital. Apart from the human capital, findings by Poli (2016) on Indian case indicate that social capital positively affects the production performance and lower production risks of smallholders in India.

Financial resources from banking or microfinance loans, informal financial societies play important role in increasing productivity of smallholder farmers too. But value of their current assets is not enough for collateral and restricts them to get loans from formal financial institutions (Proctor \& Anand, 2017:342; Fafchamps \& Schündeln, 2013).

Another important factor for capital accumulation is the government policy towards supporting farmers. Atlaw et al. (2011) on Ethiopian case indicates that government incentives to consolidation of smallholders is needed in order to get scale efficiency, and access to collective use of varied and expensive agricultural machines. However, Hairong \& Yiyuan (2015) in Chinese context argue that the capitalization of agriculture should be based on the capital belonging to rural households, rather than on capital owned by foreigners or urban sites that are encouraged by government incentives for agricultural capitalization. Because the accumulation of capital owned by outsiders relative to rural areas can have negative results, such as lower return on capital and the competitiveness of rural households in agricultural production.

Along with the traditional factors examined as determinants of physical capital accumulation, some other types of household expenditures can be tested. In Kyrgyzstan rural livelihood context household expenses on customs 
and traditions is considered as important for keeping social network ties. Participation (visiting/attendance at) and holding (conducting) events related to the customs and traditions, is the most important means of confirming the social network participation. Attendances at rituals and observances promote the expansion of social networks and the accumulation of social capital (Reeves, 2012). These events require both time and labour sources, which may decrease financial and fixed assets.

Despite the fact that is developing country with large proportion of rural population, there is a lack of quantitative studies examining capital formation of smallholder farmers. Some studies analysed different aspects of rural households, such as migration and off-farm activities (for instance, see: Atamanov and Van den Berg, 2012). This paper aims to fill out this gap and attempts to study determinants of physical capital formation among smallholder farmers in Kyrgyzstan. To our best knowledge, this is the first study on this topic in Kyrgyzstan case.

Our econometric analysis is based on cross-sectional household survey data for 2013. Physical capital is measured by non-financial (fixed) assets of households: agriculture machines, vehicles, livestock and apartment. The remainder of this paper is structured as following. Next section describes methodology and data. Section 3 presents estimations results, and section 4 concludes.

\section{Methodology and Data}

We adopt OLS regression model to analyze the impact of defined variables on physical capital stock of households in Kyrgyzstan. Formally, the specified regression model was defined as following:

$$
w^{*}=z \delta+u
$$

where $w^{*}$ is the vector of dependent variables, and $z$ is a vector of explanatory variables.

Our empirical analysis is based on household level cross-sectional data of "Life in Kyrgyzstan" survey for 2013. Data is representative at national level and includes more than 2500 households. After data formatting for our estimations, our final sample consists of 2586 households.

In our models, dependent variables are measured as different groups of household assets which are assumed as physical capital. A total asset includes vehicles, livestock and absolute value of agricultural machine and real estates except dwelling (another house). In particular, vehicle and livestock denote the absolute values (in Kyrgyz Soms) of cars, minibuses, motorcycles for the first, and livestock for the latter. Prices of these assets determined subjectively by observed household. The other three dependent variables are created using their natural logarithm to simplify interpretation and scaling.

Following the earlier empirical studies, we use variables that characterize household head, household and their location. In particular, age, gender and nationality of household head are used. Among the location indicators dummy variable indicating South regions of the country is used in order to refer to the Osh City, Jalal-Abad Oblast, Osh Oblast and Batken Oblasts. We also use household size that accounts for household member excluding migrating individuals.

In order to take into account potential cultural difference, we use household head ethnicity dummy variables. In estimations Kyrgyz nationality of household head is used as reference dummy. We also use the log value of total household income, suggesting that a higher income is associated with higher stock of household physical assets. Our models include the distance to the next main road and to the next animal market, measured in meters.

Based on previous studies we assume that social network is crucial factor affecting economic decisions of households in Kyrgyzstan. Thus, ratio of sum of household expenses on customs and traditions (celebrations, wedding, funerals and rituals) on household total expenditure determined as other explanatory variable in our models and as numeric proxy for social network.

There are two other explanatory variables: agricultural and family shocks, each of which involves a number of shocks affecting not only size of physical assets but also overall agricultural activities and generated income of household. Family shocks capture such as death and illness of household members, accidents, theft of assets, loss of job. Climate, environment and weather conditions; natural disasters, disputes over land issues, defined as events that worsen agricultural performance of households.

Natural logarithm of absolute value of total land owned by observed household used as other explanatory variable since it can help to accumulation of physical capital. Credit dummy variable indicates if households received credit from formal financial institutions within the last 12 months. Summary statistics of variables are given in the Table 1 . 


\begin{tabular}{|l|c|c|c|c|c|c|}
\hline \multicolumn{1}{|c|}{ Variable } & N & Mean & SD & $\begin{array}{c}\text { Minimum } \\
\text { Value }\end{array}$ & $\begin{array}{c}\text { Maximum } \\
\text { Value }\end{array}$ \\
\hline \multicolumn{3}{|c|}{ Dependent Variables: } \\
\hline Total assets, in Kyrgyz Soms & 2586 & 204396.6 & 424098.1 & 0 & 7600000 \\
\hline Vehicles, in Kyrgyz Soms & 2584 & 68606.1 & 135042.6 & 0 & 2205000 \\
\hline Livestock, in Kyrgyz Soms & 2584 & 76426.03 & 168868 & 0 & 4422750 \\
\hline In(Total assets) & 2586 & 7.90 & 5.76 & 0 & 15.84 \\
\hline In(Vehicles) & 2584 & 4.05 & 5.69 & 0 & 14.61 \\
\hline In(Livestock) & 2584 & 5.70 & 5.71 & 0 & 15.3 \\
\hline & Explanatory variables: & & \multicolumn{3}{|c|}{} \\
\hline Gender of HH head & 2584 & 0.72 & 0.45 & 0 & 1.00 \\
\hline Age of HH head & 2584 & 52.46 & 13.72 & 17 & 95 \\
\hline Size of HH & 2586 & 4.79 & 2.32 & 1 & 15 \\
\hline Uzbek HH & 2586 & 0.13 & 0.33 & 0 & 1 \\
\hline HH of other ethnic group & 2586 & 0.20 & 0.40 & 0 & 1 \\
\hline In(Total income) & 2586 & 10.17 & 4.22 & 0 & 14.47 \\
\hline In(Land value) & 2586 & 9.60 & 6.06 & 0 & 18.26 \\
\hline Credit dummy & 2586 & 0.10 & 0.30 & 0 & 1 \\
\hline Agricultural shocks & 2586 & 1.07 & 1.46 & 0 & 8 \\
\hline Family shocks & 2586 & 0.36 & 0.71 & 0 & 5 \\
\hline Dummy for South regions & 2586 & 0.49 & 0.50 & 0 & 1 \\
\hline Share of expenses on Customs and Trad. & 2583 & 0.07 & 0.16 & 0 & 0.93 \\
\hline
\end{tabular}

Table 1. Descriptive Statistics Source: LiK Survey 2013.

It is worth noting that the average size of the absolute value of livestock is slightly higher than vehicles. To some extent, this number indicates the features of life style of households and their investment behavior. Indeed, a cattle breeding is an important part of the daily life of rural household in Kyrgyzstan (Leeuwen et al, 1994). This is expected if one takes into account that the residence of the observed households mainly is rural (\%61.42). As for other dependent variables, vehicles can be appraised as increased due to changes in in the consumption pattern of the population in recent years.

For most variables, the total number of observation is equal to 2586 . The mean age of household head is 52.46 years. In general, the gender of the household head is more like a male, and the household size is about 5 people. Households experienced averagely 1 agricultural and less one family shocks. According to data set about half of the households live and work in the southern regions. As indicated in Table 1, an average of $7 \%$ of household expenditures refers to events related to customs and traditions.

\section{Estimation Results}

Above in the model specification, three types of home physical assets were determined as dependent variables that were measured as their absolute value. Through taking natural logarithms of these variables other three dependent variables have determined. Thereby, we estimated a total of 6 regression equations, one for each dependent variable. The estimation results for impact of defined variables in the model on stock of physical assets of households are given in the Table 2. 


\begin{tabular}{|c|c|c|c|c|c|c|}
\hline & (1) & (2) & (3) & (4) & (5) & (6) \\
\hline & Total assets & Vehicles & Livestock & In(Total assets) & $\ln$ (Vehicles) & In(Livestock) \\
\hline \multirow{2}{*}{ Gender of $\mathrm{HH}$ head } & $79172.1^{* * *}$ & $36667.1^{* * *}$ & $27390.7^{* * *}$ & $1.957^{* * *}$ & $1.976^{* * *}$ & $1.034^{* * *}$ \\
\hline & (19391.3) & $(5917.1)$ & $(7301.2)$ & $(0.230)$ & $(0.257)$ & $(0.213)$ \\
\hline \multirow{2}{*}{ Age of HH head } & $2036.8^{* *}$ & 366.0 & $1024.1^{* * * *}$ & $0.0275^{* * *}$ & 0.0146 & $0.0359^{* * * *}$ \\
\hline & $(630.2)$ & (192.3) & $(237.3)$ & $(0.00749)$ & $(0.00836)$ & $(0.00691)$ \\
\hline \multirow{2}{*}{ Size of $\mathbf{H H}$} & $15553.7^{* * *}$ & $6685.0^{* * *}$ & $4433.6^{* *}$ & $0.343^{* * *}$ & $0.405^{* * *}$ & $0.155^{* * *}$ \\
\hline & $(4043.8)$ & $(1233.6)$ & $(1522.1)$ & $(0.0480)$ & $(0.0536)$ & $(0.0443)$ \\
\hline \multirow{2}{*}{ Uzbek HH } & -23130.6 & -1903.2 & $-41157.4^{* * *}$ & $-1.343^{* * * *}$ & -0.305 & $-1.742^{* * *}$ \\
\hline & $(26316.6)$ & $(8026.9)$ & $(9904.5)$ & $(0.313)$ & $(0.349)$ & $(0.288)$ \\
\hline \multirow{2}{*}{$\begin{array}{l}\text { HH of other ethnic } \\
\text { group }\end{array}$} & -5536.2 & $16317.9^{*}$ & $-36387.8^{* * *}$ & $-0.643^{*}$ & $1.115^{* * *}$ & $-1.006^{* * *}$ \\
\hline & $(22617.4)$ & $(6900.7)$ & $(8514.9)$ & $(0.269)$ & $(0.300)$ & $(0.248)$ \\
\hline \multirow{2}{*}{$\begin{array}{l}\text { Distance to next } \\
\text { main road }\end{array}$} & 2.603 & -1.048 & $6.430^{* * *}$ & 0.0000159 & -0.000115 & $0.000143^{* *}$ \\
\hline & $(4.701)$ & (1.434) & $(1.769)$ & $(0.0000558)$ & $(0.0000623)$ & $(0.0000515)$ \\
\hline \multirow{2}{*}{$\begin{array}{l}\text { Distance to next } \\
\text { livestock market }\end{array}$} & $2.789^{* * *}$ & $-0.570^{*}$ & $2.737^{* * *}$ & $0.0000446^{* * * *}$ & -0.0000081 & $0.0000802^{* * *}$ \\
\hline & $(0.781)$ & $(0.238)$ & $(0.294)$ & $(0.00000927)$ & $(0.0000103)$ & $(0.00000856)$ \\
\hline \multirow{2}{*}{$\ln ($ Total income) } & $10705.3^{* * *}$ & $2668.1^{* * *}$ & $3620.0^{* * * *}$ & $0.227^{* * *}$ & $0.155^{* * *}$ & $0.178^{* * *}$ \\
\hline & $(2114.5)$ & $(645.0)$ & $(795.8)$ & $(0.0251)$ & $(0.0280)$ & $(0.0232)$ \\
\hline \multirow{2}{*}{ In(Land value) } & $4004.8^{* *}$ & -317.5 & $3676.5^{* * *}$ & $0.239^{* * *}$ & 0.0100 & $0.334^{* * *}$ \\
\hline & $(1526.5)$ & (465.6) & $(574.6)$ & $(0.0181)$ & $(0.0202)$ & $(0.0167)$ \\
\hline \multirow{2}{*}{ Credit dummy } & $122247.8^{* * *}$ & $38645.5^{* * *}$ & 18808.3 & $0.799^{*}$ & $1.434^{* * *}$ & 0.314 \\
\hline & $(28366.1)$ & $(8652.4)$ & $(10676.3)$ & $(0.337)$ & $(0.376)$ & $(0.311)$ \\
\hline \multirow{2}{*}{ Agricultural shocks } & 1704.3 & $-6139.5^{* * *}$ & $10805.0^{* * *}$ & $0.190^{* * *}$ & $-0.156^{*}$ & $0.504^{* * *}$ \\
\hline & $(5987.3)$ & $(1826.2)$ & $(2253.4)$ & $(0.0711)$ & $(0.0794)$ & $(0.0656)$ \\
\hline \multirow{2}{*}{ Family shocks } & 10545.9 & $-8217.6^{*}$ & 5510.5 & 0.204 & $-0.304^{*}$ & $0.421^{* * *}$ \\
\hline & (11633.8) & $(3548.4)$ & $(4378.5)$ & $(0.138)$ & $(0.154)$ & $(0.128)$ \\
\hline \multirow{2}{*}{$\begin{array}{l}\text { Dummy for South } \\
\text { regions }\end{array}$} & 5009.6 & 5059.6 & $-26965.2^{* * *}$ & $0.685^{* *}$ & 0.341 & $0.686^{* *}$ \\
\hline & $(19282.2)$ & $(5881.5)$ & $(7257.3)$ & $(0.229)$ & $(0.256)$ & $(0.211)$ \\
\hline \multirow{2}{*}{$\begin{array}{l}\text { Share of expenses on } \\
\text { Customs and Trad. }\end{array}$} & $161484.6^{* *}$ & $50114.1^{* *}$ & $91278.7^{* * *}$ & $1.939^{* *}$ & $2.351^{* * *}$ & $1.490^{* *}$ \\
\hline & $(51185.7)$ & $(15612.2)$ & $(19264.1)$ & $(0.608)$ & $(0.678)$ & $(0.561)$ \\
\hline \multirow{2}{*}{ Constant } & $-229367^{* * *}$ & $-32693^{*}$ & $-109487^{* * * *}$ & $-2.014^{* * *}$ & $-1.999^{* *}$ & $-4.062^{* * *}$ \\
\hline & $(46693.1)$ & $(14256.6)$ & $(17591.5)$ & $(0.555)$ & $(0.619)$ & $(0.512)$ \\
\hline No of Obs. & 2563 & 2562 & 2562 & 2563 & 2562 & 2562 \\
\hline$R$ squared & 0.0791 & 0.0712 & 0.184 & 0.294 & 0.105 & 0.390 \\
\hline Adj. R squared & 0.0740 & 0.0661 & 0.180 & 0.290 & 0.0999 & 0.387 \\
\hline F value & 15.63 & 13.94 & 41.05 & 75.74 & 21.30 & 116.4 \\
\hline$A I C$ & 73509.2 & 67396.2 & 68473.3 & 15375.7 & 15931.5 & 14959.0 \\
\hline$B I C$ & 73597.0 & 67484.0 & 68561.0 & 15463.4 & 16019.2 & 15046.8 \\
\hline
\end{tabular}

Table 2. OLS Regression Model Estimation Results Source: Authors' Estimation.

Most of estimated parameters are statistically significant. Coefficients predicted for gender of household head and household size, natural logarithm of total income and share of expenses on customs and traditions in all regression equations are statistically significant.

Regression model results reveal the statistical significance of the influence of the sex of the head of household and the number of household members on the volume of assets that they conducted. According to these outcomes, male-headed households have more assets than households headed by women. The household size also has a positive but lower effect than that of the household gender.

In line with our expectation sign of household total income are positive in all columns. In particular, it can be noted that its impact on the value of livestock is stronger than on vehicles. These results are realistic, as larger households have more consumption and income, and male heads are more advantageous and capable in rural areas, where households are mainly engaged in agricultural activities requiring manual labor.

Ratio for expenses on customs and traditions have positive signed coefficient and significant in all estimated equations. It should be mentioned that our assets index also reflects poverty status of household, since family with higher income have higher probability to own such assets as vehicles, apartment and livestock. On the other hand, involvement in social network activities can be larger for households with higher income. Moreover, under the conditions of scarcity of assets necessary for agricultural production social network itself may serve as an instrument to provide with necessary production inputs. This can explain positive relationship between social network involvement and physical capital accumulation.

Statistically significant coefficients of ethnicity dummies show that non-Kyrgyz households tend to own less livestock and overall assets than Kyrgyz households. The slope parameters predicted for the credit dummy indicate that households that have received loans from formal financial institutions are inclined to use borrowed funds to purchase vehicles rather than for livestock. 
Because of the simplicity of the interpretation and goodness of estimation results, we can shift our focus to the columns from 4 to 6 . The last column deserves attention, since all estimated coefficients except for the credit dummy, are statistically significant.

The results for the regional dummy variable suggest to that households that live and work in the southern Oblasts have more livestock than in other Oblasts. We assumed that experience is essential getting efficiency in agricultural activities. In compliance with our assumptions, the age of the household head has a positive effect on the aggregate of physical assets, and livestock in particular.

As for distances, the value of the estimated coefficients is small. Moreover, despite our expectations sign of coefficients are positive and significant except for columns of (2) and (5). These results can be interpreted by the fact that cattle breeding is commonly carried out in deep rural areas. These areas are far from the main roads and livestock markets that are normally organized near district or regional centers.

The value of land reflects both the quality and size of land held by households. As stated in the reported results coefficients predicted for the land value mostly have positive sign. This denotes that households with valuable land have a greater capacity for agricultural activities and more able to carry out livestock production. As this requires more feeds, pastures, buildings that in turn require more valuable land.

\section{Conclusion}

Income generated by rural households is important in position of poverty alleviation policy makers. Capital is used as main production factor in income generating activities of households. From another standpoint, the level of accumulated capital can be appraised as an outcome of economic activity of households of previous periods. At the macro level, it is also crucial to solving long-term sustainable economic development, as it can help in increasing productivity and reducing poverty. Most part of the population in Kyrgyzstan lives in rural area and involved agricultural sector. Therefore, accumulation of physical capital is important for increase income of small landholders, especially in the case of less industrialized low-income transition economies such as Kyrgyzstan.

In this paper we examined determinants of physical capital accumulation of smallholder farmers in Kyrgyzstan. Given the geographical and cultural characteristics, we analyze the livestock as one of the types of physical assets owned by households in Kyrgyzstan. In the view of the tendency towards mechanization of agricultural production and changes in the structure of consumption of the population in recent years, this study also evaluates impact of determined factors on vehicles. We used cross-sectional household survey data for 2013. Estimation results point out that size of physical assets mostly affected by the share of expenses on customs and traditions, differences in gender and ethnicity of household head. According to these findings, household management by male and/or Kyrgyz heads, wider participation in social events and activities is associated with a higher level of physical assets. Other factors that have slightly less influenced value of physical assets are access to credit, regional disparities among households, household size, value of land and total income.

However, our analysis has several limitations. First, there might be selection bias and endogeneity issue in regression modeling physical asset accumulation. Households with physical assets can have both observed and unobserved characteristics that make them distinct from others. This may result in biased estimation results. Our methodology in this study does not address this issue. One of the approaches to further modification of our methodology is to use instrumental variables approach. Second, our study considers only physical capital, while future studies can examine impact of determinants included in our models on human capital, social capital. Third, estimated effects can be conditional on potential factors such as education and health. These factors are not considered in our analysis too. Therefore, taking into account these limitations may provide with more insights into determinants of capital formation.

\section{References}

- Atamanov \& Van den Berg, 2012. "Participation and returns in rural nonfarm activities: evidence from the Kyrgyz Republic", Agricultural Economics, 43(4), pp. 459-471.

- Atlaw, Atnafu \& Saba, 2011. The Structure, Magnitude and Trends of Capital Formation in and for Agriculture in Ethiopia, Policy and Program Support Division (TCS) of FAO, A study under the framework of project "GCP/GLO/267/JPN. Retrieved from (date of access: 10.05.2018):

http://www.fao.org/fileadmin/templates/tci/pdf/CapitalFromation/Ethiopia_Final_draft_report.pdf

- $\quad$ Fafchamps, \& Schündeln, 2013. "Local financial development and firm performance: Evidence from Morocco", Journal of Development Economics, 103, 15-28.

- Glewwe, 1991. "Investigating the determinants of household welfare in Côte d'Ivoire", Journal of Development Economics, 35(2), 307-337.

- Grootaert, 1999. Social capital, houshold welfare, and poverty in Indonesia (No. 2148). The World Bank.

- Hairong, \& Yiyuan, 2015. "Agrarian capitalization without capitalism? Capitalist dynamics from above and below in China", Journal of Agrarian Change, 15(3), pp.366-391. https://doi.org/10.1111/joac.12121 
- Herr, 1964. "Capital formation: its importance and determinants", Australian Journal of Agricultural and Resource Economics, 8(2), pp. 97-111.

- Ike, \& Umuedafe, 2013. "Determinants of savings and capital formation among rural farmers in Isoko north local government area of Delta State, Nigeria", Asian Economic and Financial Review, 3(10), pp.12891297.

- Jayne, Villarreal, Pingali, \& Hemrich, 2005. "HIV/AIDS and the agricultural sector: implications for policy in Eastern and Southern Africa', Electronic Journal of Agricultural Development Economics, 2(2), pp. 158181

- Joliya, Kamalvanshi, \& Kushwaha, 2017. "Determinants of Capital Formation in Agriculture: Hadoti Region of Rajasthan”, Int.J.Curr.Microbiol.App.Sci, 6(7), pp. 4239-4245. doi: https://doi.org/10.20546/ijcmas.2017.607.439

- Leeuwen, Emeljanenko, \& Popova, 1994. Nomads in Central Asia: animal husbandry and culture in transition (19th-20th century). Koninklijk Instituut voor de Tropen (KIT)(Royal Tropical Institute, RTI).

- Manig, 1996. "The importance of the informal financial market for rural development financing in developing countries: the example of Pakistan”, The Pakistan development review, pp. 229-239.

- Mwanza, \& Speelman, 2011. Assessment of factors of household capital/assets that influence income of smallholder farmers under International Development Enterprises (IDE) in Zambia). Ghent University.

- O'Brien, Patsiorkovski, \& Dershem, 2000. Household capital and the agrarian problem in Russia. Routledge, New York. 310 p.

- Poli, 2016. Can social capital help indian smallholder farmers? Analysis of its impact on rural development, agricultural efficiency, production and risk (Doctoral dissertation, Universitat Politècnica de Catalunya).

- Proctor, \& Anand, 2017. "Is credit associated with a higher quality of life? A capability approach", Progress in Development Studies, 17(4), pp. 322-346.

- $\quad$ Reeves, 2012. "Black work, green money: remittances, ritual, and domestic economies in southern Kyrgyzstan”, Slavic Review, 71(1), pp. 108-134.

- Walle, 2003. "Are returns to investment lower for the poor? Human and physical capital interactions in rural Vietnam", Review of Development Economics, 7(4), pp. 636-653.

- Winters, Davis, Carletto, Covarrubias, Quiñones, Zezza, \& Stamoulis, 2009. “Assets, activities and rural income generation: evidence from a multicountry analysis”, World Development, 37(9), pp. 1435-1452. 